А.Є. Богомолов ${ }^{1}$, С.В. Зайков ${ }^{2}$

\title{
АНАЛІЗ ДІАГНОСТИЧНИХ ПАРАМЕТРІВ ІМУНОБЛОТИНГУ ДЛЯ ВИЗНАЧЕННЯ СЕНСИБІЛІЗАЦІЇ ДО ПИЛКОВИХ АЛЕРГЕНІВ У ПАЦІЕНТІВ З РЕСПІРАТОРНИМИ ЗАХВОРЮВАННЯМИ
}

\author{
${ }^{1}$ Вінницький національний медичний університет ім. М.І. Пирогова, \\ ${ }^{2}$ Національна медична академія післядипломної освіти ім. П.Л. Шупика
}

\begin{abstract}
Метою дослідження було порівняти діагностичні параметри різних систем дослідження методом імуноблоту для визначення сенсибілізації до алергенів пилкової групи у пацієнтів з респіраторними захворюваннями - алергічним ринітом та бронхіальною асmмою.
\end{abstract}

Матеріали і методи. В ході дослідження 88 пацієнтів з алергічним ринітом і/або атопічною астмою були обстежені трьома різними методами специфрічної алергічної діагностики (in vivo ma in vitro). Критеріями включення були діагноз алергічного риніту (як інтермітуючого, так і персистуючого) та/або атопічної астми. Прик-тест проводився за класичною методикою тестування відповідно до нормативних документів з комерційними екстрактами алергенів. Вестернблот для визначення рівнів IgE проводили з використанням тест-систем RIDA AllergyScreen (R-Biopharm AG, Дармитадm, Німеччина) i Euroline (Euroimmun).

Результати та висновки. Результати двох систем визначення специфрічного IgE до алергенів пилкової групи методами Rida AllergyScreen ma Euroline не завжди добре узгоджуються між собою внаслідок систематичної розбіжності показників.

Результати визначення специфрічних IgE до окремих алергенів в цілому добре узгоджуються між собою та з результатами шкірного тестування методом прик-тесту, втім до пилкових алергенів полину, берези, ліщини та вільхи система Euroline не завжди узгоджується з даними шкірного тестування методом прик-тесту, даючи хибно-негативні результати. Необхідний подальший аналіз узгодженості та діагностичних параметрів методів за іншими групами алергенів для узагальнення результатів дослідження. $\lg E$.
Вестерн-блот (імуноблотинг) - це техніка, яка використовується як в наукових, так і прикладних дослідженнях вже більше 3 десятків років [1]. 3 самого початку вона була розроблена як спосіб визначення конкретного білка в складному зразку. В алергології цей метод означає визначення певних імуноглобулінів різних класів у сироватці крові, що дозволяє побічно квалісрікувати рівень сенсибілізації хворого до конкретного алергену або ж алергенів [2, 3]. Провідні якості методу включають мультиплексність (адже в один і той же час визначається присутність антитіл до кількох алергенів, частіше до 20), одноразовий забір малого числа крові для вивчення і невелика кількість протипоказань [4-7]. Втім, в умовах великого обсягу іноді заангажованої інформації лікар не завжди здатний зрозуміти переваги та недоліки кожного з методів і правильно оцінити параметри їх діагностичної цінності.

Усі перераховані моменти обумовлюють необхідність не тільки зіставлення серологічних методів визначення сенсибілізації з традиційним шкірним тестуванням, але й порівняння імуноблотингу різних виробників. Наше дослідження спрямоване на визначення діагностичних параметрів імуноблоту різних виробників порівняно $з$ класичним прик-тестом у розрізі визначення сенсибілізації до пилкових алергенів.

\section{Матеріали і методи}

У процесі цього дослідження трьома різними методами специфічної алергологічної діагностики (in vivo та in vitro) було обстежено 88 хворих на бронхіальну астму та алергічний риніт. Дослідження було відкритим, проспективним, порівняльним.

Шкірне тестування проводили стандартизованим методом прик-тесту за допомогою ланцетів вітчизняними алергенами виробництва Вінницького МП «Імунолог». 
Техніка постановки шкірних тестів та оцінювання результатів шкірного тестування проводилися відповідно до наказу МО3 і АМН України № 127/18 від 02.04.2002 р. «Про організаційні заходи по впровадженню сучасних технологій діагностики та лікування алергічних захворювань».

Кількісне визначення специфрічних IgE у сироватці крові здійснювали за допомогою методу імуноблоту «Euroimmun» (Milenia Biotec $\mathrm{GmbH}$, Німеччина) та імуноблоту «RIDA® AllergyScreen» (R-Biopharm AG, Німеччина) відповідно до методик таких досліджень з інструкцій виробників.
Статистична обробка результатів, побудова діаграм і розподілів значень статистичного аналізу були виконані за допомогою програмного пакета IBM SPSS Statistics 21.

\section{Результати досліджень та їх обговорення}

За результатами шкірного тестування методом приктесту моносенсибілізацію було виявлено у 12 пацієнтів (13,3 \% випадків). Найчастіше спостерігалася сенсибілізація до таких пилкових алергенів, як жито - 34 (37,7 \%), береза - 32 (35,5 \%) та вільха - 24 (26,6 \%) випадків. Результати шкірного тестування пацієнтів наведено на малюнку 1.

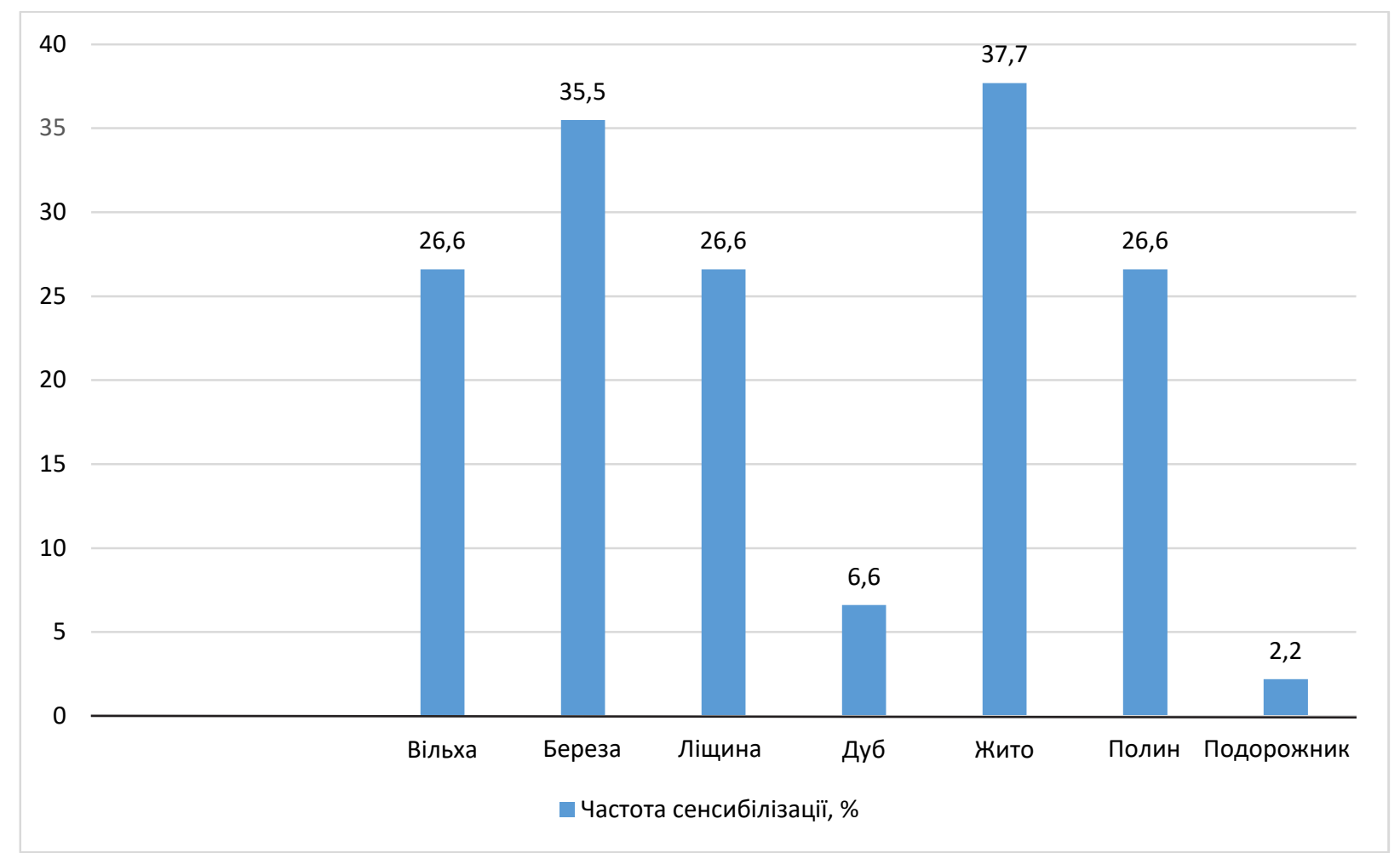

Мал. 1. Частота сенсибілізації окремими алергенами за даними прик-тестів.

Після шкірного тестування методом прик-тесту як реорерент-методу всі пацієнти були обстежені серологічним методом імуноблотингу двох різних виробників відповідно до методів дослідження.

Для якісного аналізу діагностичної значимості методів було використано ROC - аналіз, який є побудовою грасріка залежності чутливості методу від відносної кількості хибнонегативних результатів. Для прикладу наводимо графрік ROC-кривих для виявлення специфічного IgЕ методами AllergyScreen та Euroline для визначення сенсибілізації до алергенів пилку вільхи (мал. 2).

Результати кількісної оцінки побудованої кривої за допомогою обчислення площі AUC наведено у таблиці 1.
За результатами оцінки кривої виявлення специфічного IgE методом AllergyScreen, визначення сенсибілізації до алергену вільхи, берези, ліщини, полину має відмінну діагностичну значимість (AUC=0,922, 0,949, 0,941, 0,938 відповідно), виявлення специфрічного IgE методом Euroline для визначення сенсибілізації до алергену вільхи, берези, ліщини, полину - добру діагностичну значимість (AUC=0,715, 0,791, 0,773, 0,793 відповідно). В обох випадках асимптотична значимість доводить відсутність погодження нульової гіпотези (при якій істинна площа рівна 0,5) та достовірність значень площі AUC. 


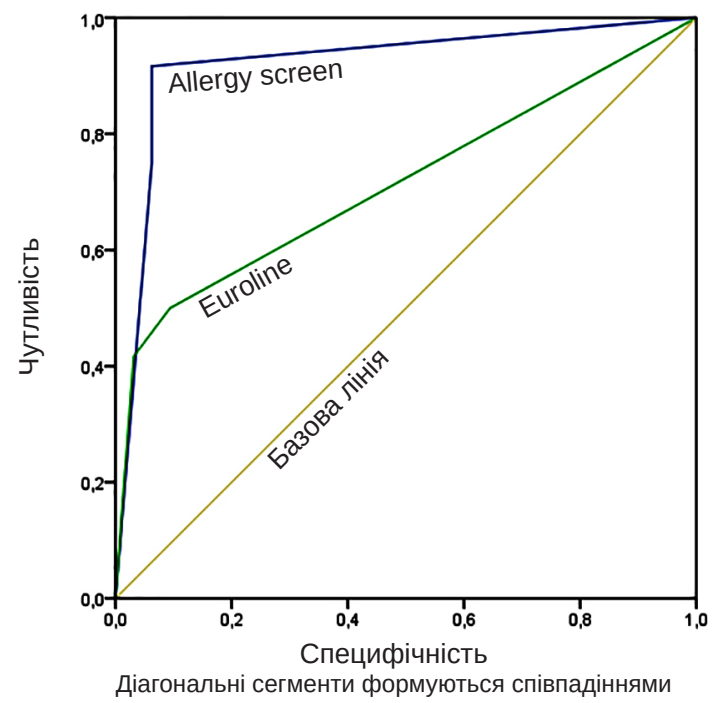

Мал. 2. ROC-крива для виявлення специфічного IgE методами AllergyScreen та Euroline для визначення сенсибілізації до алергену вільхи.
За результатами оцінки кривої виявлення специфічного IgE методом AllergyScreen, визначення сенсибілізації до алергену дуба, жита має дуже добру діагностичну значимість (AUC=0,817, 0,827 відповідно), виявлення специфічного IgE методом Euroline для визначення сенсибілізації до алергену дуба, жита - дуже добру діагностичну значимість (AUC=0,801, 0,862). В обох випадках асимптотична значимість доводить відсутність погодження нульової гіпотези та достовірність значень площі AUC.

За результатами оцінки кривої виявлення специфрічного IgE методом AllergyScreen, визначення сенсибілізації до алергену подорожника має відмінну діагностичну значимість (AUC=0,988), виявлення специфічного $\lg \mathrm{E}$ методом Euroline для визначення сенсибілізації до алергену подорожника - відмінну діагностичну значимість (AUC=0,988). В обох випадках асимптотична значимість доводить відсутність погодження нульової гіпотези та достовірність значень площі AUC.

Узагальнені результати аналізу наведено в таблиці 2.

Таблиця 1

Результати статистичної оцінки ROC-кривої для виявлення специфрічного IgE методами AllergyScreen та Euroline для визначення сенсибілізації до алергенів пилкової групи

\begin{tabular}{|c|c|c|c|c|c|}
\hline \multirow{2}{*}{ Тестові змінні } & \multirow{2}{*}{ Площа } & \multirow{2}{*}{$\begin{array}{c}\text { Стандартна } \\
\text { похибка }\end{array}$} & \multirow{2}{*}{$\begin{array}{c}\text { Асимптотична } \\
\text { значимість }\end{array}$} & \multicolumn{2}{|c|}{ Асимптотичний 95 \% довірчий інтервал } \\
\hline & & & & Нижня межа & Верхня межа \\
\hline & \multicolumn{5}{|c|}{ Вільха } \\
\hline AllergyScreen & 0,922 & 0,038 & 0,000 & 0,848 & 0,996 \\
\hline \multirow[t]{2}{*}{ Euroline } & 0,715 & 0,070 & 0,002 & 0,578 & 0,851 \\
\hline & \multicolumn{5}{|c|}{ Береза } \\
\hline AllergyScreen & 0,949 & 0,029 & 0,000 & 0,891 & 1,000 \\
\hline \multirow[t]{2}{*}{ Euroline } & 0,791 & 0,056 & 0,000 & 0,681 & 0,902 \\
\hline & \multicolumn{5}{|c|}{ Ліщина } \\
\hline AllergyScreen & 0,941 & 0,025 & 0,000 & 0,892 & 0,991 \\
\hline \multirow[t]{2}{*}{ Euroline } & 0,773 & 0,065 & 0,000 & 0,645 & 0,902 \\
\hline & \multicolumn{5}{|c|}{ Дуб } \\
\hline AllergyScreen & 0,817 & 0,117 & 0,000 & 0,587 & 1,000 \\
\hline \multirow[t]{2}{*}{ Euroline } & 0,801 & 0,116 & 0,014 & 0,573 & 1,000 \\
\hline & \multicolumn{5}{|c|}{ Жито } \\
\hline AllergyScreen & 0,827 & 0,050 & 0,000 & 0,730 & 0,924 \\
\hline \multirow[t]{2}{*}{ Euroline } & 0,862 & 0,045 & 0,000 & 0,773 & 0,950 \\
\hline & \multicolumn{5}{|c|}{ Полин } \\
\hline AllergyScreen & 0,938 & 0,026 & 0,000 & 0,887 & 0,988 \\
\hline \multirow[t]{2}{*}{ Euroline } & 0,793 & 0,062 & 0,000 & 0,671 & 0,915 \\
\hline & \multicolumn{5}{|c|}{ Подорожник } \\
\hline AllergyScreen & 0,988 & 0,012 & 0,019 & 0,966 & 1,000 \\
\hline Euroline & 0,988 & 0,012 & 0,019 & 0,966 & 1,000 \\
\hline
\end{tabular}




\section{ОРИГІНАЛЬНІ ДОСЛІДЖЕННЯ}

Таблиця 2

Результати статистичного аналізу порівняння діагностичної значимості визначення специфічного IgЕ до кліщових та епідермальних алергенів методами AllergyScreen та Euroline порівняно з прик-тестом

\begin{tabular}{|l|l|l|}
\hline \multicolumn{1}{|c|}{ Погодженість } & \multicolumn{1}{|c|}{ AllergyScreen } & Euroline \\
\hline Відмінна & $\begin{array}{l}\text { Подорожник } \\
\text { Полин } \\
\text { Береза } \\
\text { Ліщина } \\
\text { Вільха }\end{array}$ & Подорожник \\
\hline Дуже добра & $\begin{array}{l}\text { Жито } \\
\text { Дуб }\end{array}$ & $\begin{array}{l}\text { Жито } \\
\text { Дуб }\end{array}$ \\
\hline Добра & & $\begin{array}{l}\text { Полин } \\
\text { Береза } \\
\text { Ліщина } \\
\end{array}$ \\
& & Вільха \\
\hline
\end{tabular}

\section{Література}

1. Зайков С.В. Современные подходы к лабораторной диагностике аллергических заболеваний / С.В. Зайков, А.Е. Богомолов // Новости медицины и фрармации. - 2013. - № 14(465). - C. 45-50.

2. Season of birth, childhood asthma and allergy in a nationwide cohort-Mediation through lower respiratory infections / C. Almqvist, S. Ekberg, S. Rhedin, F. Fang // C. Clin. Exp. Allergy. - 2019/ - Nov 29. doi: 10.1111/cea.13542. [Epub ahead of print]

3. Tsutsumi H. Respiratory tract infection and allergy / H. Tsutsumi // Arerugi. - 2019. - Vol. 68(9). - P. 1121-1125. doi: 10.15036/ arerugi.68.1121.

4. The importance of real-life research in respiratory medicine: manifesto of the Respiratory Effectiveness Group: Endorsed by the International Primary Care Respiratory Group and the World Allergy Organization / N. Roche, A. Anzueto, S. Bosnic Anticevich

\section{Висновки}

1. Таким чином, результати двох систем визначення специфічного IgE до алергенів пилкової групи методами Rida AllergyScreen та Euroline не завжди добре узгоджуються між собою внаслідок систематичної розбіжності показників.

2. Результати визначення специфічних IgE до окремих алергенів в цілому добре узгоджуються між собою та з результатами шкірного тестування методом приктесту, втім до пилкових алергенів полину, берези, ліщини та вільхи система Euroline не завджи узгоджується 3 результатами шкірного тестування методом прик-тесту, даючи хибно-негативні результати. Необхідний подальший аналіз узгодженості та діагностичних параметрів методів за іншими групами алергенів для узагальнення результатів дослідження. [et al.] // Eur. Respir. J. - 2019. - Vol. 54, N 3. pii: 1901511. doi: 10.1183/13993003.01511-2019. Print 2019 Sep.

5. García-Solaesa V. SDS-Polyacrylamide Electrophoresis and Western Blotting Applied to the Study of Asthma / V. García-Solaesa, S.C. Abad // Methods Mol. Biol. - 2016. - Vol. 1434. - P. 107-120. doi: 10.1007/978-1-4939-3652-6_8.

6. Casset A. How In Vitro Assays Contribute to Allergy Diagnosis / A. Casset, N. Khayath, F. de Blay // Curr. Aller Asthma Rep. - 2016. - Vol. 16(11). - P. 82.

7. Chauveau A. Disagreement between Skin Prick Tests and Specific IgE in Early Childhood / A. Chauveau // Int. Arch. Allergy Immunol. - 2016. - Vol. 170(2). - P. 69-74. doi: 10.1159/000446776. Epub 2016 Jul 26.

\section{References}

1. Zaykov, S. V., \& Bogomolov, A. E. (2013). Modern approaches to laboratory diagnosis of allergic diseases. News of Medicine and Pharmacy, 14 (465): $45-50$ [in Russian].

2. Almqvist, C., Ekberg, S., Rhedin, S., Fang, F. (2019). Season of birth, childhood asthma and allergy in a nationwide cohort-Mediation through lower respiratory infections. C. Clin. Exp. Allergy, Nov 29. doi: 10.1111/cea.13542. [Epub ahead of print]

3. Tsutsumi, H. (2019). Respiratory tract infection and allergy. Arerugi, 68 (9), 1121-1125. doi: 10.15036/arerugi.68.1121.

4. Roche, N., Anzueto, A., Anticevich, S. B., Kaplan, A., Miravitlles, M., Ryan, D., ... \& Canonica, G. W. (2019). The importance of real-life research in respiratory medicine: manifesto of the Respiratory Effectiveness Group: Endorsed by the International Primary
Care Respiratory Group and the World Allergy Organization. Eur. Respir. J., 54(3). pii: 1901511. doi: 10.1183/13993003.01511-2019. Print 2019 Sep.

5. García-Solaesa, V., \& Abad, S. C. (2016). SDS-polyacrylamide electrophoresis and Western blotting applied to the study of asthma. In Molecular Genetics of Asthma (pp. 107-120). Humana Press, New York, NY. doi: 10.1007/978-1-4939-3652-6_8.

6. Casset, A., Khayath, N., \& de Blay, F. (2016). How in vitro assays contribute to allergy diagnosis. Current Allergy and Asthma Reports, 16 (11), 82.

7. Chauveau, A. (2016). Disagreement between skin prick tests and specific IgE in early childhood. Int. Arch. Allergy Immunol., 170 (2), 69-74. doi: 10.1159/000446776. Epub 2016 Jul 26. 


\section{ANALYSIS OF IMMUNOBLOTTING DIAGNOSTIC PARAMETERS FOR DETERMINATION OF SENSIBILIZATION TO POLLEN ALLERGENS IN PATIENTS WITH RESPIRATORY DISEASES}

A.Ye. Bogomolov ${ }^{1}$, S.V. Zaykov²

${ }^{1}$ M. Pyrohov Vinnytsia National Medical University,

${ }^{2} \mathrm{P}$. Shupyk National Medical Academy of Postgraduate Education

SUMMARY. The aim of the study was to compare the diagnostic parameters of different systems of serological examination by immunoblot method for the determination of sensitization to allergens of pollen group in patients with respiratory allergic diseases - allergic rhinitis and bronchial asthma.

Materials and methods. In the study, 88 patients with allergic rhinitis and/or atopic asthma were examined with three different methods of specific allergic diagnosis (in vivo and in vitro). Inclusion criteria were a diagnosis of allergic rhinitis (both intermittent and persistent) and/ or atopic asthma. The pre-test was conducted according to the classic test method according to the normative documents with commercial allergen extracts. Western blots for the determination of IgE levels were performed using RIDA AllergyScreen test systems (R-Biopharm AG, Darmstadt, Germany) and Euroline (Euroimmun).

Results and conclusions. The results of two systems for determining specific IgE for pollen allergens by the Rida AllergyScreen and Euroline methods do not always agree very well due to the systematic divergence of indicators.

The results of determining specific IgE for individual allergens are generally in good agreement with each other and the results of skin testing by the prick test, however, for pollen, birch, hazel and alder pollen allergens, the Euroline system does not always match the results of skin testing by the prick test. negative results. Further analysis of the consistency and diagnostic parameters of the methods for other allergen groups is necessary to summarize all the results of the study.

Key words: prick-test; allergy; immunoblotting; IgE.

\section{Відомості про авторів:}

Богомолов Артемій Євгенович - к. мед. н., доцент кафедри фртизіатрії з курсом клінічної імунології Вінницького національного медичного університету ім. М.І. Пирогова; e-mail: art.bogomolov@gmail.com;

ORCID ID: https://orcid.org/0000-0002-5336-4858

Зайков Сергій Вікторович - д. мед. н., професор кафедри фртизіатрії та пульмонології НМАПО ім. П.Л. Шупика; e-mail: zaikov1960@gmail.com;

ORCID ID: https://orcid.org/0000-00029276-0490

Information about the authors:

Bogomolov A.Ye. - PhD, Associate Professor of Phthisiology, Clinical Immunology and Allergy Department, M.I. Pyrohov Vinnytsia National Medical University; e-mail: art.bogomolov@gmail.com

ORCID ID: https://orcid.org/0000-0002-5336-4858

Zaykov S.V. - MD, Professor of the Department of Phthisiology and Pulmonology P.L. Shupyk National Medical Academy of Postgraduate Education; e-mail: zaikov1960@ gmail.com

ORCID ID: https://orcid.org/0000-00029276-0490

Конорлікт інтересів: немає.

Authors have no conflict of interest to declare.

Отримано 18.02.2020 p. 